\title{
Jurnal Penelitian Ilmu Pendidikan
}

\section{KORELASI ANTARA INTERAKSI SOSIAL TERHADAP HASIL BELAJAR AFEKTIF SISWA KELAS V DI SDN SE-KECAMATAN KALIWATES JEMBER}

\author{
Dini Ratna Sari, Mutrofin, Chumi Zahroul Fitriyah \\ Universitas Jember, Universitas Jember, Universitas Jember \\ E-mail: ratnasaridini49@yahoo.co.id
}

\begin{abstract}
Abstrak
Interaksi sosial adalah hubungan antara individu satu dengan individu yang lain, individu yang satu dapat mempengaruhi individu yang lain sehingga terdapat timbal balik. Semakin baik interaksi sosial siswa maka akan semakin baik pula hasil belajarnya. Hasil belajar yang dikaji dalam penelitian ini adalah hasil belajar afektif. Penelitian ini bertujuan untuk mengungkap apakah semakin baik interaksi sosial semakin baik hasil belajar afektif siswa kelas V di SDN se-Kecamatan Kaliwates Jember. Populasi penelitian ini adalah siswa kelas V SDN seKecamatan Kaliwates Jember. Penelitian ini merupakan penelitian korelasi dengan jumlah populasi 182 dan sampel 25 siswa. Metode pokok pengumpul data berupa angket dan observasi. Untuk menguji hipotesis penelitian menggunakan rumus korelasi product moment dengan bantuan SPSS 20 pada taraf signifikansi 5\%. Hasil analisis penelitian diperoleh nilai $r_{\text {hitung }}>\mathrm{r}_{\text {tabel }}(0,748>0,266)$ dan koefisien determinasi $56 \%$. Hal ini menunjukkan bahwa interaksi sosial memiliki kontribusi sebesar 56\% terhadap hasil belajar afektif sisanya $44 \%$ dipengaruhi oleh faktor lain. Maka dapat disimpulkan bahwa semakin baik interaksi sosial maka semakin baik pada hasil belajar afektif siswa kelas V SDN se-Kecamatan Kaliwates Jember.
\end{abstract}

Kata Kunci: Interaksi Sosial, dan Hasil Belajar Afektif

\section{(THE CORRELATION BETWEEN SOCIAL INTERACTION AND AFFECTIVE LEARNING OUTCOME OF THE5TH GRADE STUDENTS IN ELEMENTARY SCHOOLS IN KALIWATES SUB- DISTRICT, JEMBER REGENCY)}

\author{
Dini Ratna Sari, Mutrofin, Chumi Zahroul Fitriyah \\ Universitas Jember, Universitas Jember, Universitas Jember \\ E-mail: ratnasaridini49@yahoo.co.id
}

\begin{abstract}
Social interaction is the relationship between one individual and another individual, one individual can influence other individuals so that there is reciprocity. The better the students' social interactions, the better their learning outcomes will be. Learning outcomes examined in this study are affective learning outcomes. This study aims to reveal whether the better social interaction, the better the affective learning outcomes of fifth grade students in SDN throughout Kaliwates Jember District. The population of this research is the fifth grade students of SDN in Kaliwates Jember District. This study is a correlation study with a population of 182 and a sample of 25 students. The main methods of collecting data are questionnaire and observation. To test the research hypothesis using the product moment correlation formula with the help of SPSS 20 at a significance level of 5\%. The results of the research analysis obtained the value of $r_{-}$count $>r_{-}$tabel $(0.748>0.266)$ and the coefficient of determination $56 \%$. This shows that social interaction has a contribution of $56 \%$ to affective learning outcomes the remaining $44 \%$ is influenced by other factors. It can be concluded that the better social interaction, the better the affective learning outcomes of fifth grade students of SDN in Kaliwates Jember District.
\end{abstract}

Keywords: Social Interaction, and Affective Learning Outcomes 


\section{Jurnal Penelitian Ilmu Pendidikan}

\section{PENDAHULUAN}

Hakikatnya manusia merupakan makhluk yang memiliki dua fungsi, yaitu sebagai makhluk individual dan makhluk sosial. Sebagai makhluk individusi manusia memiliki potensi dan kemampuan intelektual masing-masing yang berbeda. Sedangkan, sebagai makhluk sosial manusia memiliki kemampuan bersosialisasi dengan orang lain. Dalam kehidupannya, manusia selalu membutukan bantuan orang lain untuk memenuhi kebuthan hidupnya. Begitu juga dengan pendidikan, manusia dapat mewujudkan tujuan pendidikan dengan adanya interaksi dan komunikasi sosial dengan manusia lainnya. Malihah dan Effendi (2011: 32) mengemukakan bahwa ada beberapa alasan manusia dapat dikatakan sebagai makhluk sosial yaitu meliputi: 1) manusia tunduk pada aturan, norma sosial, 2) perilaku manusia mengharapkan suatu penilaian dari orang lain, 3) manusia memiliki kebutuhan untuk berinteraksi dengan orang lain, 4) potensi manusia akan berkembang bila ia hidup di tengah-tengah manusia. Kemampuan intelektual dan sosialisasi dapat dikembangkan melalui proses belajar. Hal ini dapat tercapai melalui proses pendidikan, yang mana pendidikan sangat penting bagi manusia.

Dalam proses pendidikan, penting adanya interaksi dengan manusia lain guna mewujudkan tujuan pendidikan. Tujuan pendidikan tidak akan tercapai apabila di dalam proses belajar mengajar tidak ada interaksi yang berlangsung. Malihah dan Effendi (2011: 34) mengemukakan bahwa interaksi adalah proses dimana orang-orang berkomunikasi saling mempengaruhi dalam fikiran dan tindakan. Walgito (dalam Virgia, 2014) interaksi sosial adalah hubungan individu satu dengan individu lain, individu satu dapat mempengaruhi individu yang lain atau sebaliknya, jadi terdapat adanya hubungan saling timbal balik. Berdasarkan pemaparan diatas dapat disimpulkan bahwa interaksi sosial

merupakan hubungan timbal balik antara individu satu dengan yang lain yang dapat mempengaruhi fikiran dan tindakan individu tersebut.

Purwanto (2014)hasil belajar adalah tolok ukur yang digunakan untuk mengukur tingkat keberhasilan siswa. Ada dua faktor yang mempengaruhi hasil belajar meliputi faktor internal dan faktor eksternal. Menurut Slameto (2003: 54-60) faktor internal meliputi faktor jasmani, faktor psikologis, dan faktor kelelahan. Selain faktor internal juga dipengaruhi oleh faktor-faktor eksternal. Aunurrahman (2014: 187) faktor eksternal adalah faktor yang ada di luar siswa yang dapat mempengaruhi aktivitas dan hasil belajar siswa. Adapun faktor-faktor eksternal yang mempengaruhi hasil belajar siswa meliputi lingkungan sosial, kurikulum, sekolah, sarana dan prasarana. Lingkungan sosial berperan penting bagi siswa, apabila ada siswa yang berteman dengan anak yang rajin maka siswa tersebut akan termotivasi untuk lebih giat lagi dalam belajar. Berlaku sebaliknya apabila siswa berteman dengan anak yang kurang serius dalam belajar maka siswa tersebut akan terbawa perilaku seperti itu. Hal ini dapat menimbulkan masalah dalam proses belajar.

Berdasarkan pengalaman KK-PLP di SDN Kepatihan 01 Jember pada kelas VC dan VD peneliti mengamati pada saat kegiatan pembelajaran siswa masih sulit menyampaikan pendapat, kurang kerja sama dengan siswa lain, dan kurang menghargai saat siswa menyampaikan suatu pendapat singga menimbulkan kegaduhan di dalam kelas. Suasana kelas yang tidak kondusif atau gaduh akan mempengaruhi proses pembelajaran sehingga dapat berdampak pada hasil belajar siswa. 


\section{Jurnal Penelitian Ilmu Pendidikan}

Dari hasil penelitian menunjukkan bahwa hasil interaksi sosial yang baik maka hasil belajar siswa yang baik. Hal ini berdasarkan penelitian yang dilakukan Fernanda, dkk. (2012) dengan judul "Hubungan kemampuan interaksi sosial dengan hasil belajar" menunjukkan adanya hubungan antara kemampuan interaksi sosial dengan hasil belajar sebesar 0,619 dengan taraf signifikan 0,01. Hal ini berarti apabila kemampuan interaksi siswa baik maka hasil belajar siswa baik begitupun sebaliknya kemampuan interaksi siswa tidak baik maka hasil belajar siswa tidak baik.

Dari beberapa temuan yang ada, kecenderungan siswa dalam berinteraksi di lingkungan kelasnnya dan perbedaan hasil belajar yang siswa dapat, maka peneliti tertarik ingin mengadakan penelitian tentang "Korelasi antara Interaksi Sosial terhadap Hasil Belajar Afektif Siswa Kelas V di SDN seKecamatan Kaliwates Jember. Berdasarkan urain latar belakang yang telah dijabarkan, maka rumusan masalah untuk penelitian ini yaitu: "apakah semakin baik interaksi sosial siswa semakin baik hasil belajar afektif siswa kelas V di SDN seKecamatan Kaliwates Jember".

\section{METODE PENELITIAN}

Jenis penelitian ini adalah penelitian korelasi. Penelitian korelasi (Masyhud, 2016:130) merupakan penelitian yang berusaha untuk mengetahui ada tidaknya hubungan antara dua variabel atau lebih. Metode yang digunakan dalam penelitian ini adalah kuantitatif karena data yang disajikan berhubungan dengan angka dan analisis statistik. Penelitian ini dilakukan untuk mengetahui seberapa besar tingkat study korelasi antara interaksi sosial terhadap hasil belajar. Dalam penelitian ini diasumsikan apabila siswa berinteraksi sosial dengan baik maka hasil belajar siswa lebih optimal. Sugiyono (2015:90) mengemukakan populasi adalah wilayah generalisasi yang terdiri atas objek dan subjek yang mempunyai kualitas dan karakteristik tertentu yang ditetapkan oleh peneliti untuk dipelajari dan kemudian ditarik kesimpulannya. Populasi penelitian ini adalah siswa kelas $\mathrm{V}$ di SDN seKecamatan Kaliwates sebanyak 182 siswa. Masyut (2016:98) mengemukakan bahwa sampel acak sederhana (simple random sampling) biasanya dilakukan dengan cara undian atau lotre dari nomornomor subjek yang ada dalam populasi. Teknik ini memberikan peluang atau hak kepada semua subjek dalam populasi untuk dijadikan sampel. Pada penelitian ini mengambil 5 siswa dari setiap sekolah sehingga jumlah siswa yang menjadi sampel sebanyak 25 siswa. Variabel pada penelitian ini adalah interaksi sosial $(X)$ dan hasil belajar afektif (Y). Dalam penelitian ini terdapat sembilan indikator yang terdiri dari percakapan, melakukan kontak mata, saling pengertian, bekerja sama, keterbukaan, empati, memberikan dukungan atau motivasi, rasa positif, dan adanya kesamaan dengan orang lain.. Teknik pengumpulan data dalam penelitian ini menggunakan metode angket atau kuesioner dan observasi. Sebelum angket digunakan untuk mengumpulkan data penelitian, angket yang telah dibuat harus dilakukan uji coba terlebih dahulu untuk memperoleh alat ukur yang sahih (valid) dan handal (reliabel). Teknik analisis data dalam penelitian menggunakan uji koefien korelasi dan uji determinan.

\section{HASIL DAN PEMBAHASAN}

Berdasarkan analisis uji coba instrumen memperoleh hasil berupa uji validitas dan uji reliabilitas. Uji validitas diujikan pada dua validator ahli serta 38 siswa diluar populasi. Uji validitas angket dari dua validator memperoleh hasil presentase sebesar $83,33 \%$ sehingga masuk 


\section{Jurnal Penelitian Ilmu Pendidikan}

dalam kategori layak. Uji validitas lembar observasi dari dua validator memperoleh hasil presentase sebesar $83,75 \%$ sehingga masuk dalam kategori layak. Uji reliabilitas dalam penelitian ini menggunakan rumus Alpha berbantuan SPSS versi 20 diperoleh hasil sebesar 0,894 sehingga $r_{\text {hitung }}>0,60$ dan dinyatakan reliabel.

Hasil analisis pengujian hipotesis terdiri dari dari uji koefisien korelasi, dan uji determinasi. Dalam analisis uji koefisien korelasi menggunakan rumus korelasi product moment berbantuan SPSS versi 20 memperoleh hasil sebesar 0,748 sehingga yang dihasilkan yaitu sebesar 0,748 yang berada pada rentang $0,80 \leq \mathrm{r} \leq$ 1,000 yang menunjukkan bahwa antara variabel $\mathrm{X}$ dan variabel $\mathrm{Y}$ terdapat korelasi yang sangat kuat. Pada uji signifikansi uji, koefisien korelasi diperoleh sebesar 0,748 pada signifikasi $5 \%$ dari $\mathrm{N}=25$ sebesar 0,266. Hasil analisis tersebut dapat diketahui bahwa nilai lebih besar dari $(0,748>0,266)$. Demikian dapat dikatakan bahwa semakin baik interaksi sosial maka semakin baik pula hasil belajar afektif siswa kelas $\mathrm{V}$ di SDN se-Kecamatan Kaliwates Jember. Dalam uji determinasi diperoleh persentase sebesar 56\%. sehingga dapat dikatakan bahwa interaksi sosial dapat meningkatkan hasil belajar afektif sebesar $56 \%$, dan $44 \%$ dipengaruhi oleh faktor lainnya.

Sedangkan hasil korelasi interaksi sosial untuk masing-masing indikator dengan hasil belajar afektif yakni indikator 1 diperoleh hasil 0,860 dengan kontribusi sebesar $74 \%$, indikator 2 diperoleh hasil 0,309 dengan kontribusi sebesar 10\%, indikator 3 diperoleh hasil 0,594 dengan kontribusi sebesar 35\%, indikator 4 diperoleh hasil 0,710 dengan kontribusi sebesar $50 \%$, indikator 5 diperoleh hasil 0,532 dengan kontribusi sebesar 28\%, indikator 6 diperoleh hasil 0,358 dengan kontribusi sebesar $13 \%$, indikator 7 diperoleh hasil 0,780 dengan kontribusi sebesar 61\%, indikator 8 diperoleh hasil 0,458 dengan kontribusi sebesar $21 \%$, indikator 9 diperoleh hasil 0,678 dengan kontribusi sebesar $46 \%$. Dari perhitungan tersebut dapat dikatakan bahwa indikator 1 yakni percakapan memperoleh hasil korelasi dan sumbangan kontribusi yang paling tinggi dan indikator 2 yaitu melakukan kontak mata memperoleh sumbangan kontribusi yang paling rendah. Artinya dalam proses interaksi sosial percakapan mempunyai peran penting bagi siswa untuk mencapai hasil belajar afektif siswa yang optimal sedangkan melakukan kontak mata hanya sebagai pendukung saja.

Berdasarkan hasil penelitian, dapat dilihat bahwa semakin baik interaksi sosial siswa maka semakin baik pula hasil belajarnya. Hal ini sesuai dengan pendapat Aunurrahman (2014:187) menyatakan bahwa keberhasilan siswa selain ditentukan oleh faktor internal tetapi juga dipengaruhi faktor eksternal siswa. faktor eksternal adalah faktor yang ada diluar diri siswa yang memberikan pengaruh terhadap aktivitas dan hasil belajar yang dicapai siswa. Faktor eksternal meliputi guru, lingkungan sosial (teman sebaya), kurikulum sekolah, sarana dan prasarana. Siswa sebagai makhluk sosial tidak mungkin lepas dari interaksi dengan lingkungan, terutama dengan temanteman sebayanya. Selaras dengan pendapat Elly (2006:95) menyatakan bahwa manusia berinteraksi dengan sesamanya dalam kehidupan untuk mengahasilkan pergaulan hidup dalam suatu kelompok. Manusia dalam kehidupan seharihari tidak lepas dari hubungan individu yang satu dengan individu lain.

Interaksi sosial antar siswa haruslah berjalan dengan baik, karena tidak sedikit siswa yang mengalami peningkatan hasil belajar karena pengaruh teman sebaya 


\section{Jurnal Penelitian Ilmu Pendidikan}

yang mampu memberikan motivasi kepadanya untuk belajar. Demikian juga banyak siswa yang mengalami perubahan sikap karena teman-teman sekolah memiliki sikap positif yang dapat ditiru dalam pergaulan atau interaksi sehari-hari. Menurut Bimo Walgito dalam Dayaksini (2009:105) bahwa interaksi sosial merupakan hubungan antara individu satu dengan individu lainny sehingga terdapat hubungan yang saling timbal balik. Interaksi sosial siswa tidak baik ditandai dengan hubungan antar siswa yang diliputi rasa kebencian, dan kurangnya kerjasama diantara siswa. Selain itu, interaksi sosial siswa yang baik ditandai dengan pemberian dukungan (motivasi) dan penerimaan yang baik dari teman serta lingkungan belajar. Hal ini sangat mempengaruhi semangat belajar sehingga dapat meningkatkan hasil belajar.

Hasil dari lembar observasi hasil belajar afektif yang memiliki 9 indikator dan 27 deskriptor, tidak semua nampak dalam pembelajaran. Hal ini dikarenakan deskriptor pada setiap indikator ada yang namapk jelas oleh peneliti dan ada uga yang tidak nampak. Misalnya kesediaan untuk membuka diri, peka terhadap yang dialami teman, dan menempatkan diri pada situasi yang dialami teman. Deskriptor-deskriptor tersebut tidak semuanya dapat namapk jelas terlihat oleh peneliti karena keterbatasan kemampuan peneliti.

Dalam pembelajaran interaksi sosial berperan penting sehingga siswa dapat memperoleh hasil belajar yang optimal. Berdasarkan hasil uji hipotesis sebesar 0,748 menunjukkan bahwa ada hubungan yang signifikan antara interaksi sosial dengan hasil belajar, maka dapat disimpulkan bahwa $\mathrm{H}_{0}$ ditolak dan $\mathrm{H}_{\mathrm{a}}$ diterima. Hal ini berarti semakin baik interaksi sosial maka semakin baik baik pula hasil belajar afektif siswa.

\section{KESIMPULAN DAN SARAN}

Berdasarkan hasil analisis dan pembahasan yang telah dipaparkan pada bab 4 dapat disimpulkan bahwa semakin baik interaksi sosial semakin baik pula hasil belajar afektif siswa kelas V di SDN seKecamatan Kaliwates Jember. Hal ini ditunjukkan dengan perolehan nilai $\mathrm{r}_{\text {hitung }}$ adalah 0,748 . Nilai $r_{\text {tabel }}$ dengan $\mathrm{N}=25$ pada taraf kesalahan 5\% yaitu 0,266. Nilai $\mathrm{r}_{\text {hitung }}>\mathrm{r}_{\text {tabel }}$ maka $\mathrm{H}_{0}$ ditolak dan $\mathrm{H}_{\mathrm{a}}$ diterima. Sumbangan kontribusi variabel interaksi sosial dengan hasil belajar afektif tersebut diperoleh sebesar $56 \%$, sedangkan sisanya sebesar $44 \%$ dipengaruhi oleh faktor lain yang tidak dibahas dalam penelitian ini.

Berdasarkan kesimpulan yang diperoleh, maka saran yang diberikan adalah sebagai berikut.

a. Pihak guru, guru sebaiknya lebih memperbanyak kegiatan pembelajaran dengan melibatkan siswa berperan aktif dalam kelompok, agar interaksi sosial antar siswa terjalin dengan baik.

b. Pihak peneliti, peneliti yang ingin meneliti interaksi sosial siswa, penelitian ini dapat dijadikan acuhan atau referensi untuk membantu dalam melakukan penelitian. Selain itu karena penelitian ini baru mengungkapkan tentang hubungan antara interaksi sosial siswa dengan hasil belajar afektif diharapkan peneliti lain dapat melanjutkan penelitian ini dengan membahas interaksi sosial dikaitkan dengan faktor lain.

\section{DAFTAR PUSTAKA}

Ahmadi, A. 2009. Psikologi sosial. Jakarta: Rineka Cipta

Aunurrahman. 2014. Belajar dan pembelajaran. Bandung : Alfabeta 


\section{Jurnal Penelitian Ilmu Pendidikan}

Effendi, R. dan Malihah, E. 2011. Panduan Kuliah Pendidikan Lingkungan Sosial, Budaya, Teknologi. CV. Maulana Media Grafika: Bandung.

Fitriastuti, F.2013. Pengaruh Interaksi Sosial dalam Keluarga dan Minat Belajar Siswa terhadap Hasil Belajar Siswa.

Kolip, Elly M Setiadi dan Usman. 2011. Pengantar Sosiologi. Pemahaman Fakta dan Gejala Permasalahan Sosial: Teori, Aplikasi, dan Pemecahannya. Jakarata: Kencana

Masyhud, M. S. 2016. Metode Penelitian Pendidikan. Jember: Lembaga Pengembangan Manajemen dan Profesi Kependidikan.

Mishabuddin, I. 2013. Analisis Data Penelitian dengan Statistik. Jakarta: Bumi Aksara

Fernanda, Mistio dkk. 2012. Hubungan Kemampuan Interaksi Sosial dengan Hasil Belajar. Nomor 2

Muslim, A. 2013. Interaksi Sosial dalam Masyarakat Multietnis. Volume 1 nomor 2

Mutrofin. 2018. Hasil Pem(belajar)an: Teori dan Pengukurannya. Yogyakarta: LaksBang PREssindo.

Nuraida, A. 2017. Pengaruh Interaksi Sosial terhadap Aktivitas Belajar Siswa Kelas IV SD Selabu Kecamatan Mangunrejo.

Nurwati, A. 2009. Hubungan Antara interaksi Sosial Siswa dengan
Hasil Belajar Bahasa Indonesia Siswa Madrasah Ibtidaiyah Sekabupaten Gorontalo. Nomor 2

Purnomo. 2008. Metodologi Penelitian Sosial. Jakarta: PT Bumi Aksara

Purwanto. 2014. Evaluasi Hasil Belajar. Yogyakarta: PUSTAKA PELAJAR

Poerwanti. 2013. Asimilasi dan Akulturasi: Sebuah Tinjauan Konsep. Jurnal Negeri Jogyakarta.

Rifa'i, A. 2012. Psikologi pendidikan. Semarang: Pusat Pengembangan MKU/MKDK UNNES

Rizki. 2016. Hubungan Antara Interaksi Sosial Teman Sebaya Dengan Kemadirian Remaja Pada Peserta Didik Kelas X Di SMK MUHAMMADIYAH 2 Kediri.

Roni, Muhammad. 2015. Kemampuan Berinteraksi pada Peserta Didik. Jurnal Diskursus Islam. (3):2-3.

Rusman. 2012. Belajar dan Pembelajaran Berbasis Komputer: Mengembangkan Profesionalisme Abad 21. Bandung: ALFBETA

Selsedani, Tori. dkk. 2015. Hubungan Interaksi Sosial dengan Hasil Belajar Siswa SMA Negeri 7 Bandar Lampung. Volume 3 nomor 7

Slameto. 2003. Belajar dan faktor-faktor yang mempengaruhinya. Jakarta: PT Rineka Cipta

Soekanto, S. 2010. Sosiologi suatu pengantar. Jakarta: Rajawali Pers 


\section{Jurnal Penelitian Ilmu Pendidikan}

Soekanto, S. 2014. Sosiologi suatu pengantar. Jakarta: Rajawali Pers

Sugiyono. 2015. Metode Penelitian Pendidikan. Bandung: Alfabeta

Sudjana, Nana. 2004. Penilaian Hasil BelajarMengajar. Bandung: PT Remaja Rosdakarya

Sukmadinata, Nana. 2011. Landasan Psikologi Sosial Proses Pendidikan. Bandung: PT Remaja Rosdakarya

Widodo, P. B. 2006. Reabilitas dan Validitas Kontruk Skala Konsep Diri untuk Mahasiswa Indonesia. Jurnal Psikologi Universitas Diponegoro. (3):2-3. 